\title{
코성형수술의 전망
}

인하대학교 의과대학 이비인후과학교실

장 태 영 - 정 동 학

\section{The Future of Rhinoplasty}

Tae-Young Jang, MD and Dong-Hak Jung, MD

Department of Otolaryngology-Head \& Neck Sungery, College of Medicine, In Ha University, Sungnam, Korea

서 언

생활수준의 향상은 순수한 미용 목적의 코성형을 증가 시켜왔으며 아울러 산업의 발달과 함께 각종 사고로 인 한 코뼈의 골절은 원래 코 모양으로의 복원을 위한 코성 형의 필요성 역시 증가시켰다. 그동안 코성형은 코를 올 리는 사치스러운 수술로만 여겨져 학문적 발달이 다소 늦은 경향이 있었다. 그러나 코성형은 단순히 코를 올리 는 순수 미용 수술이나 휘어진 코를 바로잡는 수술에서 부터 선천적 기형의 교정, 종양이나 사고로 인한 결손부 재건까지 광범위한 분야를 포함하고 있다. ${ }^{1)}$ 외모에 드러 난 코기형에 의한 정신적 상처는 때로 어떠한 질환보다 더 심각한 장애를 초래할 수 있다. 부비동염이나 알러지 성 비염등 눈에 드러난 질환의 치료도 중요하나 외모에 의 한 정신적 상처도 역시 똑같이 치료하여야 할 질환의 하나 이다. 미용목적이거나 치료를 위한 목적이던지 코성형의 폭팔적 잠재력을 간과할 수 없으며 차후 비과영역에서 이 에 대한 좀더 많은 관심과 노력이 필요할 것으로 생각한다.

\section{본 문}

과거 부비동염이나 만성중이염같은 감염성질환이 주

교신저자 : 정동학, 461- 190 경기도 성남시 수정구 태평동 3309- 327 인하대학교 의과대학 이비인후과학교실 전화 : (0342) 720- 5849. 전송 : (0342) 720- 5239 E- mail : Rhinojdh@ netsgo.com.
를 이루어 왔다면 향후 생활수준과공중위생의 향상은 이 러한 질환의 유병율은 감소시킬 것이며 아울러 순수 미 용목적의 수술에 대한 욕구를 증가시킬 것이다. 최근 인 천지역 20 30대를 대상으로한 설문조사에서 대상자의 $5.2 \%$ 에서 자신의 코가 못생겼으며 기회가 닿는다면 수 술하고 싶다고 하였다. ${ }^{2)}$ 또한 이미 $1.7 \%$ 는 코성형수술 을 받은 것으로 조사되었다. ${ }^{2)}$ 유등의 조사에 의하면 조 사 대상자의 $7.8 \%$ 가 이미 미용수술을 받은 것으로 보 고하였다. ${ }^{3)}$ 이렇게 일반인들중 코성형수술을 받고자 하 는 사람들의 수치는 1991년에 조사된 만성중이염의 빈 도 $2.19 \%$ 보다 2.5 배정도 높은 것으로 향후 어려원진 의료환경에서 대처해 나가야 할 방향을 제시해주고 있 다. ${ }^{4}$ 현재까지도 비과영역에서 미미한 정도의 코성형이 시행되어지고 있다. 인하대주최의 제1회 코성형술연수 회에 참석했던 T oriumi(1990)에 의하면 미국내에서 이 미 $70 \%$ 이상의 코성형술이 이비인후과 의사에 의하여 수 행되어지고 있다고 하였다. ${ }^{5)}$ 현존하는 최고의 코성형수 술 대가인 T ardy 와 Gunter 등은 물론 현재 가장 활발 한 활동을 펴고있는 T oriumi역시 이비인후과 의사이다. 물론 어떤수술을 하는데 있어 과가 중요한 것은 아니라 누구의 결과가 더 좋은가가 중요하다. 하지만 코는 외모 뿐 아니라 기능적인 면에서도 중요한 역할을 하고 있다. 따라서 코를 가장 잘 이해하고 전공하는 분야에서 수술 을 시행하는 것이 자연스러운 일이다. 이제 비과 영역에 서 코성형수술의 활성화는 부인할 수 없는 대명제이다. 그것은 단순히 비과영역의 확장이라는 문제를 넘어서 사 
활이 달린 문제일 수도 있다. 그러기 위해서는 넘어야 할 벽이있다면 그것은 부작용없이 더 좋은 결과를 얻는 것이다. Shirakabe(1998) 는 현재 대부분의 의사들이 Business- oriented되어 있어 새로운 기술의 습득이나 개발보다는 돈을 벌 수 있는데 치중하고 있다고 비판하 였다. ${ }^{6)}$ 이러한 비판은 하나의 실마리를 주고 있는데, 기 존의 벽을 넘기위하여 병원수입등 경제적인 논리에서가 아니라 환자의 입장에서 새로운 재료와 기술의 습득, 그 리고 코성형은 사치스러운 수술만이 아닌 질병치료의 하 나라는 개념의 도입이 필요하다. 실제로 구순열코같은 선 천성 질환을 포함하여 많은 비기형환자들이 외모로 인 한 자기혐오로 심한 정신적 갈등을 겪고 있다(Fig. 1). 이
러한 환자들의 치료는 실제로 술자에게 더많은 보람과 희열을 안겨준다. 특히 선천성기형을 가진 부모의 죄의 식은 보통의 후천적질환에 의한 것과는 비교가 되지 않 는다. 따라서 전술한바와 같이 코성형을 받으려는 환자 도 다른질환과 똑같은 환자라는 입장에서의 접근이 필 요하다.

코성형수술을 시행하는데 있어 가장 문제가 되는 것 은 의사의 입장에서 부작용에 대한 우려이다. 실제로 의 료사고에 의한 소송건수는 94년에 274건, 95년에 282 건, 96년에 319건등으로 매년 13\% 정도 증가하고 있다. 3 년간 875 건의 의료소송중 77 건 $8 \%$ 가 성형외과와 연 관된 것이였다( 중앙일보 96. 11. 27. 21면). 마찬가지로
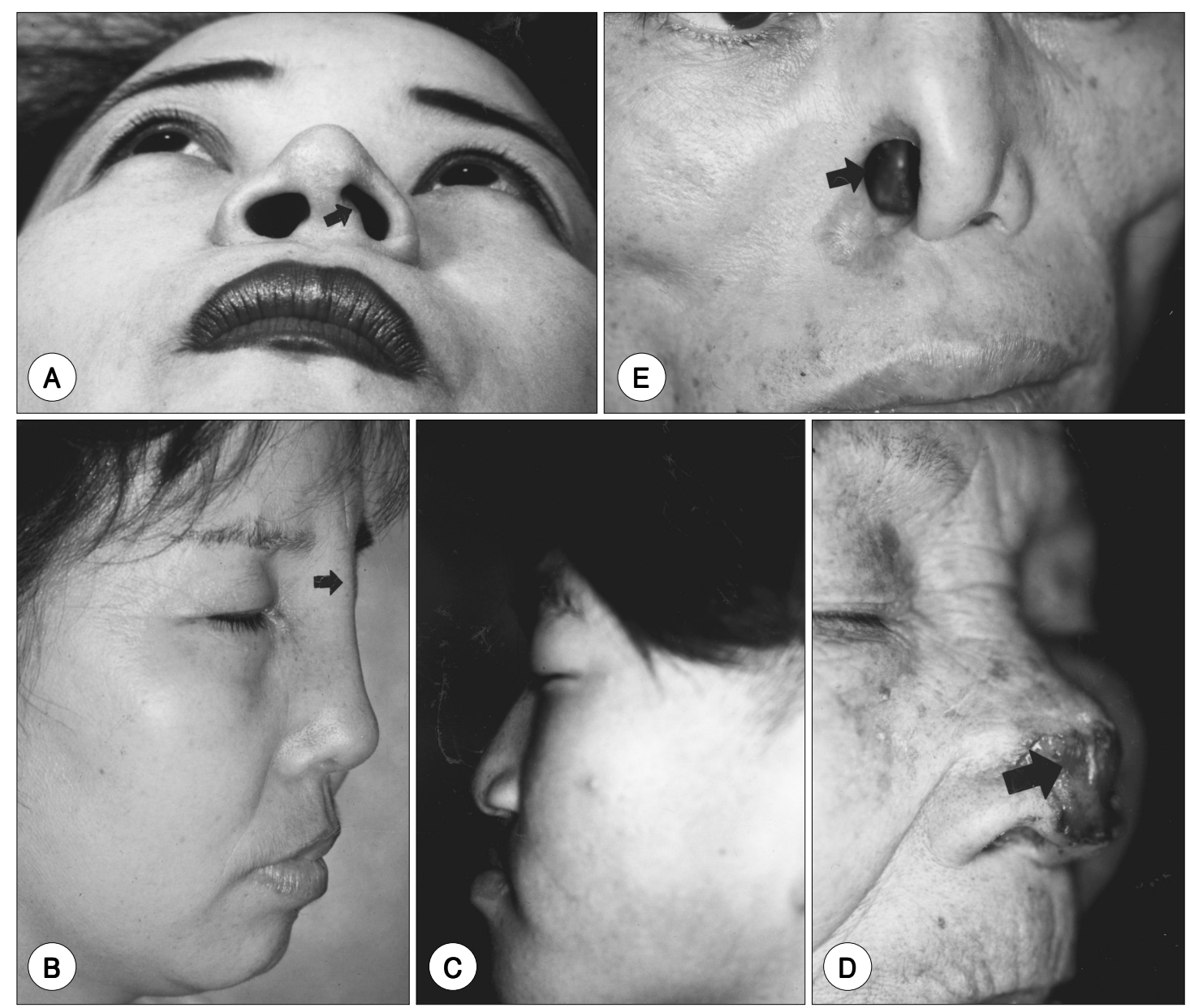

Fig. 1. These photographs show examples of atypical nasal deformities. A. Asymmetric nares ( Arrow) B. High grabellar ( Arrow) C. Basal cell cancer on the nasal tip ( Arrow) D. Cleft lip nose E. Alar defect ( Arrow) . 
코성형을 받고자 하는 사람들의 입장에서도 코성형술을 받는데 가장 꺼리게 되는 이유로써 부작용에 대한 우려 가 전체 응답자의 $61 \%$ 를 차지하였다. ${ }^{2)}$ 이러한 부작용 을 줄이고 학문적인 활성화를 위하여 코성형의 연수회나 심포지움의 개최는 물론 학회차원에서 지속적인 관심과 지원이 필요하겠다. 끝으로 비과영역에서 코성형 필요성 의 이유를 다시 정리하면 첫째, 코성형술하면 실리콘을 연상하며 학문적으로 큰 의미가 없는 것으로 간과하기 쉬 우나 현재까지도 학설이 완전히 정립되지 않고 자기의 방법을 주장하거나 고수하는 곳이 바로 코성형술 분야 이다. 이말은 바꾸어 말하면 학문적으로 아직 정립되지 않아 더 연구할 여지가 많다는 뜻이다. 둘째, 경제적인 면에서 코성형은 어떤 수술보다 부가가치가 높은 수술 이다. 셋째, 앞으로 생활수준의 향상은 미용성형수술에 대한 급격한 증가가 예상된다. 넷째, 코성형은 순수 미 용적인 것 뿐아니라 기능적인 문제부터 코전체의 재건 까지 다양하고 넓은 분야를 포함하므로 코성형 수술을 시행하는 것 자체가 비과영역의 확장을 의미한다. 다섯 째, 미용수술은 다른 수술과는 달리 창조적과정이 요구되 며 아름다움을 창조하는 예술적이 작업의 하나이다.

이상과 같은 필요성을 떠나더라도 코성형수술은 꼭 권해주고 싶은 매력적인 수술이며 가까운 미래에 코를 정말 잘 이해하고 코성형수술을 잘하는 곳은 이비인후 과 의사라는 인식이 확산되기 위하여 학회차원에서의 지 속적인 관심과 각 개인 스스로도 많은 노력을 경주하여 야 할 것이다.

\section{결 론}

생활수준의 향상은 염증성질환의 감소와 함께 미용수 술에 대한 욕구를 증가시키고 있다. 이러한 경향은 점
차 갈수록 강해질것으로 예상된다. 선진각국의 경우 코 성형수술의 많은 부분이 이미 이비인후과영역에서 수행 되어지고 있다. 차후 코성형수술은 비과영역에서 마치 현 재의 부비동질환이나 알러지질환처럼 중요한 역할을 차 지할것으로 확신한다. 따라서 이에 대비한 보다많은 연 구와 투자가 필요할 것으로 생각하며 각 개인들도 스스 로 이에 대비하는 것이 필요하겠다. 새로운 영역에 대한 도전에 있어서 처음부터 경제적인 목적으로의 접근은 기득권의 거센 반발을 불러올 것이므로 환자의 입장에 서 학문적인 접근을 통하여 더좋은 수술 결과로써 승부 하는것이 자연스럽고 후발주자가 살아남을 수 있는 길이 다. 이를위해 차별화되는 새로운 재료와 신기술의 개발 및 습득, 그리고 부작용에 대한 철저한 분석과 학문적 연구, 학회차원에서의 지원, 개개인의 노력이 합쳐지는 것이 비과 영역에서 코성형술이 살아남을 수 있는 유일 한 방법이며 미래에 대비하는 일이라 생각한다.

중심 단어 : 코성형술.

\section{REFERENCES}

1) Baek SI, Jung DH, Min YG. Rhinoplasty. In Min YG (ed). Cli Rhino, Seoul, Il-Jo-Gak;1997, p.507-763.

2) Yun YS, Park JW, Jung DH. External nasal appearances preferred by Koreans from the twenties to thirties. Korean J Otolaryngol 1997;40(8):1122-7.

3) Yoo YC, Lee DH, Chang CH. A study of the attitude of patients undergoing aesthetic surgery. Korean J Plast Surg 1994;21(3):452-9.

4) Kim CS, Jung HW, Hong SH, et al. A prevalence study of otitis media and related disease in Korea in 1991. Korean J Otolaryngol 1993;36(3):459-65.

5) Johnson CM, Toriumi DM. Open structure rhinoplasty. philadelphia, WB Saunders Company, 1990.

6) Shirakabe Y. The current trends \& advances of oriental aesthetic surgery. proceeding of 6th International congress of oriental aesthetic plastic surgery;1998 Dec 6-9, HongKong, p.61. 